\title{
Penelitian Pelestarian Dan Pemanfaatan Sumberdaya Arkeologi
}

\author{
Muhammad Hidayat
}

Keywords: cultural resource management, conflicts, regulation, conservation, heritage

\section{How to Cite:}

Hidayat, M. (1997). Penelitian Pelestarian Dan Pemanfaatan Sumberdaya Arkeologi. Berkala Arkeologi, 17(1), 24-32. https://doi.org/10.30883/jba.v17i1.766

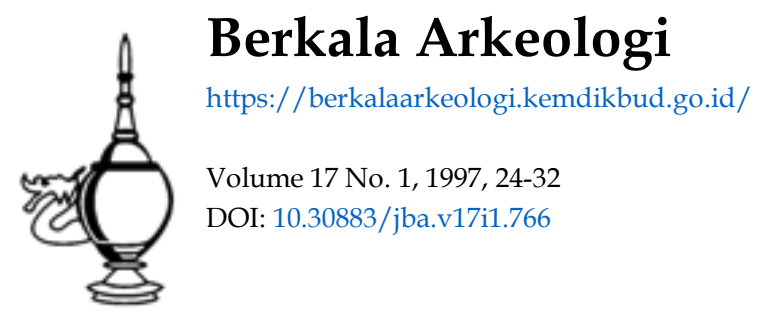

\section{cc) (i) (2)}

This work is licensed under a Creative Commons Attribution-NonCommercial-ShareAlike 4.0 International License. 


\section{Muhammad Hidayat \\ (Balai Arkeologi Yogyakarta)}

\section{Latar Belakang}

Dalam pembangunan yang sedang gencar-gencarnya dilaksanakan di Indonesia dewasa ini sering terjadi konflik-konflik kepentingan antar sektoral. Sektor yang kurang menghasilkan barang maupun jasa, sering terkalahkan dalam konflik tersebut. Dalam kasus semacam ini banyak masalah kelestarian sumberdaya arkeologi terancam.

Sebenamya masalah konflik yang dapat mengancam kelestarian sumberdaya arkeologi tersebut tidak akan terjadi apabila koordinasi, integrasi, dan sinkronisasi antar sektoral dilakukan secara optimal dalam penyusunan program. Selain itu dirasakan pula masih kurangnya terhadap permahaman aspek- aspek hukum yang mengatur masalah kepentingan antar sektoral.

Masalah kelestarian sumberdaya arkeologi, sebenarnya tidak lepas pula dari masalah pemahaman Pemerintah Daerah terhadap makna keberadaan sumberdaya arkeologi yang berada didaerahnya untuk kepentingan pembangunan, khususnya pembangunan daerah. Masih banyak sumberdaya arkeologi yang belum dimanfaatkan secara maksimal oleh karena keterbatasan sumberdaya manusianya, dalam hal ini sumberdaya manusia yang mampu mengelola sumberdaya arkeologi tersebut.

\section{Aspek Hukum Pelestarian dan Pemanfaatan}

Berkaitan dengan masalah pelestarian sumberdaya arkeologi ada beberapa aspek hukum yang dapat diacu, diantaranya seperti berikut.

1. TAP MPR Nomor II/MPR/1993 tentang GBHN 1993 - 1998, khususnya pada Kebijakan Pembangunan Lima Tahun Keenam (di bidang kebudayaan).

2. UU No. 4 Tahun 1982 tentang Ketentuan-ketentuan Pokok Pengelolaan Lingkungan Hidup.

3. UU No. 5 Tahun 1992 tentang Benda Cagar Budaya.

4. UU RI No. 24 Tahun 1992 tentang Penataan Ruang.

5. PP No. 29 Tahun 1986 tentang AMDAL.

6. PP No. 51 Tahun 1993 tentang AMDAL.

7. Keppres RI No. 32 Tahun 1990 tentang Pengelolaan Kawasan Lindung.

8. Kep. Men. Negara Lingkungan Hidup RI No. Kep- 11/MENLH/3/1994 tentang Jenis Usaha atau Kegiatan yang wajib Dilengkapi dengan AMDAL.

Sementara itu berkenaan dengan pemanfaatan sumberdaya arkeologi aspek-aspek hukum yang dapat diacu diantaranya seperti berikut. 


\section{TAP MPR Nomor II/MPR/1993 tentang GBHN 1993 - 1998. khususnya pada Kebijakan Pembangunan Lima Tahun Keenam (di bidang Kebudayaan). \\ 2. UU No. 5 Tahun 1992 tentang Benda Cagar Budaya.}

\section{Penelitian untuk Pelestorian dan Pemanfastan Sumberdaya Arkeologi}

Untuk melestarikan dan-memanfaatkan sumberdaya arkeologi harus dilakukan penelitian lintas sektoral, yaitu terhadap obyek dan lingkungan sumberdaya arkeologi tersebut maupun terhadap program-program sektor lain yang terkait. Adapun langkah-langkah penelitian tersebut paling tidak seperti berikut.

\section{Penelitian untuk Pelestarian}

1. Estimasi Sumberdaya Arkeologi

Membuat gambaran sumberdaya arkeologi yang berisi deskripsi dan informasi yang dapat dijaring, diantaranya seperti berikut.

a. Jenis dan Jumlah : Adalah jenis-jenis sumberdaya arkeologi yang terjaring dan jumlah masing-masing jenis tersebut. Misal: masjid, makam/kompleks makam, benteng, perkampungan kuna, sisa-sisa permukiman, arca, yoni. candi/kompleks candi, dolmen, batu dakon, menhir, dll.

b. Distribusi : Adalah sifat sebaran sumberdaya arkeologi. Misal: terkosentrasi, tersebar secara acak, tersebar dalam kelompok-kelompok/unit-unit tertentu. berpola, dll.

c. Luas/batas situs : Adalah luas situs berdasarkan sebaran sumberdaya arkeologi
secara horisontal.

d. Kondisi : Adalah kondisi sumberdaya arkeologi saat ini yang men yangkut keutuhan, keterawatan, pemanfaatan, dan usaha pelestarian yang telah dilakukan.

e. Informasi sejarah budaya : Adalah sejarah budaya mengenai sumberdaya arkeologi yang diperoleh dari penelitian tersebut (interpretasi), sumber sekunder, maupun cerita yang berkembang dalam masyarakat (legenda).

2. Argumentasi Pelestarian

Memuat alasan mengenai perlunya dilakukan pelestarian karena mengandung nilai penting baik dari segi kesejarahan, ilmu pengetahuan, kebudayaan, maupun dari segi sosial-ekonomi.

a. Tinjauan segi kesejarahan : Sumberdaya arkeologi bernilai penting karena berkaitan dengan peristiwa-peristiwa penting dan tokoh-tokoh sejarah tertentu, baik tokoh lokal maupun nasional. 
b. Tinjauan segi ilmu pengetahuan : Sumberdaya arkeologi bemilai penting karena dapat dipergunakan untuk mengembangkan ilmu pengetahuan pada disiplin ilmu-ilmu tertentu, dapat menjelaskan kasus- kasus tertentu. Misal: di bidang kesenian. arsitektural, teknologi, sosial-ekonomi, lingkungan, dll.

c. Tinjauan segi kebudayaan : Sumberdaya arkeologi bernilai penting karena berkaitan/mendukung keberadaan/kelangsungan kebudayaan masyarakat setempat. Misal: kerajinan tradisional, kesenian tradisional, dan adat istiadat lainnya.

d. Tinjauan segi sosial-ekonomi : Sumberdaya arkeologi bernilai penting karena bermanfaat bagi masyarakat setempat, pemerintah daerah, maupun masyarakat luas dalam hubungan sosial maupun peningkatan ekonomi. Misal: ada rasa ikatan batin antara masyarakat setempat dengan obyek, obyek merupakan kebanggan daerah maupun nasional, obyek sebagai sarana pendidikan, obyek merupakan asset wisata yang dapat membantu ekonomi masyarakat setempat, pemerintah daerah, maupun nasional.

3. Permasalahan Keberadaan Sumberdaya Arkeologi

Merupakan permasalahan yang mengancam keberadaan dan kelestarian sumberdaya arkeologi akibat pengelolaan (pelestarian dan pemfungsian) maupun pengembangan wilayah, baik yang telah berlangsung maupun diperkirakan akan berlangsung. Permasalahan tersebut diangkat/diperoleh berdasarkan observasi di lapangan (pada obyek, situs, dan sekitarnya), rencana pengembangan wilayah di sekitar/kawasan situs (BAPPEDA), dan tinjauan penerapan ketentuan/peraturan yang terkait seperti UU No. 4 Tahun 1982, UU No. 5 Tahun 1992, UU No. 24 Tahun 1992, Keppres No. 32 Tahun 1990, dll.

\section{Analisis Permasalahan}

Adalah menganalisis semua permasalahan mengenai pelestarian yang mengancam sumberdaya arkeologi yaitu pada skope obyek, situs/lahan, dan pada skope lanskap. Tujuan analisis ini adalah untuk mengetahui/memperkirakan bentuk, besaran (kualitas dan kuantitas) ancaman, dan dampaknya pada sumberdaya arkeologi serta penyebab munculnya ancaman tersebut.

a. Pada obyek

Membahas kerusakan obyek (lihat kondisi obyek pada butir 1), yaitu bagian, bentuk/tingkat kerusakan, serta penyebab kerusakan tersebut. Mengenai kerusakan tersebut, baik yang telah berlangsung maupun yang diperkirakan akan berlangsung, baik yang berkaitan dengan pengelolaan (perawatan. pemanfaatan) maupun pengembangan wilayah. 
Misal:

- Balok-balok batu pada jirat-jirat makam situs $x$ banyak yang pecah dan lapuk akibat ditumbuhi rumput dan semak-semak liar. Pada situs tersebut tidak ada pengelolanya.

- Bangunan $x$ akan dapat menjadi retak-retak dan runtuh bagian atapnya. Hal tersebut akibat getaran kendaraan berat pengangkut material bangunan kawasan industri yang akan dibangun.

b. Pada situs/lahan

Adalah menganalisis permasalahan yang telah muncul dan diperkirakan akan muncul yang mengancam kelestarian obyek dan situs di dalam areal situs. Pada analisis ini di bahas mengenai bentuk dan tingkat kerusakan serta penyebabnya, baik yang disebabkan karena pengelolaan (perawatan. pemanfaatan, dan penataan situs) maupun pengembangan wilayah. Misal:

- Pemusnahan sebagian areal situs oleh pemanfaatan kepentingan lain seperti untuk areal parkir, kios cendera mata dsb. Hal tersebut terjadi karena belum adanya zoning dan kesadaran mengenai UU Cagar Budaya.

- Adanya kekumuhan dan penenggelaman obyek-obyek oleh bangunanbangunan tambahan di areal situs yang disebabkan oleh ketidaktahuan prinsip-prinsip dalam pengelolaan situs.

c. Pada lanskap

Adalah menganalisis permasalahan di lingkungan areal situs (kawasan), baik yang telah muncul maupun yang diperkirakan akan muncul dan mempengaruhi kelestarian obyek maupun situs. Penganalisisan ini ditujukan untuk mengetahui/memperkirakan bentuk dan tingkat kerusakan serta penyebabnya. Kerusakan terseburt pada fisik obyek/situs maupun non fisik, dan biasanya disebabkan oleh pengembangan wilayah yang tidak terkendali. Misal:

- Terjadinya reduksi situs sebagai akibat pertumbuhan permukiman yang dirangsang oleh penetapan kawasan industri di sekitar situs.

- Retaknya bangunan yang disebabkan oleh getaran mesin pabrik.

- Tenggelamnya kemegahan/tampilan arsitektural karena adanya bangunanbangunan baru di sekitar situs atau di dalam kawasan perkampungan kuna, yang lebih tinggi atau yang tidak selaras arsitekturalnya.

Rekomendasi

Rekomendasi berupa saran atau masukan pada pengelola maupun Pemerintah Daerah setempat untuk kepentingan Pemerintah Daerah, masyarakat setempat. maupun masyarakat luas. Muatan rekomendasi paling tidak mengandung unsur 
penanggulangan atau pemecahan masalah untuk pelestarian. Rekomendasi berupa bentuk-bentuk usaha pelestarian ini berdasarkan pada masing-masing penyebab permasalahan (dalam analisis permasalahan), misalnya seperti berikut ini.

- Pembersihan

Adalah usaha pembersihan seperti numput, tanaman liar, dsb yang tumbuh pada obyek/situs yang mengganggu kebersihan maupun keutuhan obyek.

- Preservasi/konservasi

Adalah penanganan terhadap obyek yang membutuhan perawatan secara teknis kimiawi.

- Rehabilitasi

Adalah penanganan terhadap bangunan yang telah dirubah bentuknya, yang ditujukan untuk mengembalikan bentuk dan jenis bahan semula.

- Pemugaran

Adalah kegiatan untuk menangani bangunan yang telah runtuh dan memungkinkan untuk direkonstruksi.

- Penataan situs

Adalah kegiatan untuk mengatur terhadap pemanfaatan ruang yang tidak terhindarkan lagi di dalam ar areal situs, sehingga situs tidak terkesan kumuh, kotor, dan merusak sumberdaya arkeologi yang ada.

- Zoning

Adalah kegiatan pembagian ruang dan pemanfaatannya pada areal situs dan lingkungannya untuk mengamankan situs dari ancaman luar (akibat pengembangan wilayah). Di dalam zoning paling tidak terdapat 2 zone (zone inti dan zone penyangga), dan disesuaikan dengan dimensi obyek/situs, besaran ancaman, dan pemanfaatannya.

- Penataan kawasan

Adalah kegiatan yang ditujukan untuk mengendalikan pengembangan perubahan lahan dan jenis kegiatan, khususnya yang berupa pendirian bangunan baru, perubahan banguman, dan perubahan pernanfaatan pada kawasan yang mengandung sumberdaya arkeologi.

- Penetapan Kawasan Cagar Budaya

Adalah usaha yang ditujukan untuk mengamankan kawasan yang mengandung sumberdaya arkeologi dari perubahan-perubahan bentuk lahan maupun pemanfaatan akibat pengembangan wilayah. 
- AMDAL

Adalah suatu studi lingkungan bagi pemrakarsa kegiatan/usaha yang memenuhi kriteria wajib AMDAL (Kep. 11/MENLH/3/94, Lamp. I), dalam hal ini mengancam kelestarian Kawasan Cagar Budaya.

\section{- Penyuluhan}

Dimaksud penyuhuhan di sini adalah penyuluhan mengenai sumberdaya arkeologi dan segala aspek hukumnya yang terutama ditujukan kepada pengelola, masyarakat sekitar situs, dan Aparat Pemda.

\section{Penelitian untuk Pemanfaatan}

1. Estimasi Sumberdaya Arkeologi

Gambaran sumberdaya arkeologi yang berisi deskripsi dan informasi seperti jenis dan jumlah, distribusi, luas situs, kondisi, dan informasi sejarah budaya.

2. Analisis Sejarah Budaya

Menganalisis mengenai latar belakang keberadaan sumberdaya arkeologi yang meliputi masa, fungsi, keterkaitan dengan peristiwa tertentu maupun tokoh tertentu, serta keterkaitannya dengan kebudayaan tradisional yang hidup pada masyarakat saat ini.

3. Kebijakan Pembangunan Daerah/Wilayah yang Terkait

Gambaran kebijakan daerah khususnya mengenai pembangunan yang bersentuhan/berkaitan dengan kelestarian dan pemanfaatan sumberdaya arkeologi.

4. Analisis Potensi

Menganalisis potensi sumberdaya arkeologi untuk pengembangan.

a. Nilai Penting : Tinjauan nilai-nilai yang terkandung di dalam dan pada keberadaan sumberdaya arkeologi, khususnya nilai kesejarahan. ilmu pengetahuan, kebudayaan, serta sosial-ekonomi.

b. Keterkaitan dengan Sektor Lain : Tinjauan program/kebijakan pembangunan daerah, khususnya pada sektor-sektor yang bersentuhan atau berkaitan dengan keberadaan sumberdaya arkeologi, baik pada masalah kelestarian maupun pemanfaatan, yang mendukung maupun yang mengancam. Sektor-sektor yang bersentuhan maupun yang berkaitan tersebut diantaranya pertambangan, perindustrian (besar. kecil. tradisional). PU, kehutanan. Dikbud, dan pariwisata.

c. Permasalahan Pengembangan : Tinjauan terhadap masalah-masalah yang dihadapi apabila sumberdaya arkeologi tersebut akan dikembangkan. baik yang menyangkut masalah pelestarian maupun sarana penunjang. 
5. Bentuk Pengembangan

Mencari bentuk-bentuk dan prioritas pengembangan sumberdaya arkeologi yang sesuai berdasarkan bobot nilai-nilai yang terkandung dan kebijakan pembangunan daerah (program daerah yang mendukung).

a. Bobot Pengembangan

Memberikan nilai sesuai standar yang disepakati terhadap nilai-nilai yang terkandung dalam dan pada keberadaan sumberdaya arkeologi. yaitu nilai kesejarahan, ilmu pengetahuan, kebudayaan. dan sosial-ekonomi. Dalam pemberian nilai harus dilakukan seobyektif mungkin dan mengacu pada analisis potensi, khususnya pada nilai Openting. Untuk menghindari subyektivitas dalam pemberian nilai, penilaian dapat dilakukan beberapa orang dan kemudian dicocokan/ dirata-rata (cross checking).

Contoh standar penilaian:

$\begin{array}{lll}\text { Sangat kurang } & = & 1 \\ \text { Kurang } & = & 2 \\ \text { Cukup } & = & 3 \\ \text { Tinggi } & = & 4 \\ \text { Sangat tinggi } & = & 5\end{array}$

b. Prioritas Pengembangan Pemanfaatan

Mendapatkan prioritas sumberdaya arkeologi yang dikembangkan. Prioritas ini didapatkan berdasarkan besamya rata-rata nilai penting.

c. Indikasi Program Pengembangan Pemanfaatan

Penyusunan program pemanfaatan sumberdaya arkeologi berdasarkan pada nilai penting dan kebijakan pembangunan daerah (program BAPPEDA/sektor-sektor terkait). Dalam penyusunan program ini perlu pula dibahas permasalahan dalam pengembangan pemanfaatan tersebut, seperti masalah pelestarian dan sarana penunjang.

Bentuk-bentuk pemanfaatan sumberdaya arkeologi tersebut diantaranya sebagai obyek wisata (budaya, kota, ziarah), koleksi museum daerah, sarana peraga pendidikan, ajang penelitian ilmu pengetahuan, sarana memperkokoh jati diri daerah/bangsa, sebagai citra kawasan (land mark), dsb. 


\section{KEPUSTAKAAN}

Anonim. Pedoman Pelaksanaan Peraturan Pemerintah No. 29 Tahun 1986 tentang Analisis Mengenai Dampak Lingkungan. Sekretariat Menteri Negara Kependudukan dan Lingkungan Hidup, 1987.

Anonim. Undang-undang RI Nomor 5 Tahun 1992 tentang Benda Cagar Budaya. Departemen Pendidikan dan Kebudayaan. 1992.

Anonim. Undang-undang RI Nomor 24 Tahun 1992 tentang Penataan Ruang.

Anonim. Garis-garis Besar Haluan Negara 1993 - 1998, TAP MPR Nomor II/ MPR/1993. Jakarta: Sinar Grafika. 1993.

Anonim. Peraturan Pemerintah RI Nomor 51 Tahun 1993 tentang Analisis Mengenai Dampak Lingkungan.

Anonim. Keputusan Meoteri Negara Lingkungan Hidup RI No. Kep 11/ MENLH/3/1994 tentang Jenis Usaha atau Kegiatan yang Wajib Dilengkapi dengan Analisis Mengenai Dampak Lingkungan.

Kusumohartono, Bugie. 1992. Sumberdaya Budaya dan Prospek Kepariwisataan Kawasan Pagu, Kediri, Jawa Timur, makalah ceramah yang diselenggarakan Yayasan Hondodento di Pendopo Sendang Tirtakamandanu, Menang, Pagu, Kediri, Jawa Timur, Sabtu, 27 Juni 1992.

Kusumohartono, B. 1993. Penelitian Arkeologi dalam Konteks Pengembangan Sumberdaya Arkeologi. Makalah dalam Lokakarya Intern tentang Penelitian, AMDAL dan Pelestarian Sumberdaya Arkeologi di Balai Arkeologi Yogyakarta. 10 -11 Maret 1993.

Kusumohartono, B. 1993. Penelitian Arkeologi dengan Subkajian tentang Pelestarian Sumberdaya Arkeologi, makalah dalam Lokakarya Intern tentang Penelitian, AMDAL dan Pelestarian Sumberdaya Arkeologi di Balai Arkeologi Yogyakarta. 10- 11 Maret 1993.

Kusumohartono, B. M. (1993). Penelitian Arkeologi Dalam Konteks Pengembangan Sumberdaya Arkeologi. Berkala Arkeologi, 13(2), 46-57. https://doi.org/10.30883/ jba.v13i2.576 
Kusumohartono, B. (1994). Penelitian Arkeologi Indonesia Pasca UU Nomor 5 Tahun 1992. Berkala Arkeologi, 14(1), 36-44. https://doi.org/10.30883/jba.v14i1.628

Kusumohartono, B. 1995. Manajemen Sumberdaya Budaya: Pendekatan Strategis dan Taktis. Makalah dalam Seminar Metodologi Riset Arkeologi di Fakultas Sastra Universitas Indonesia, Depok, Januari 1995.

Tim Studi. 1995. Laporan Akhir Studi Perencanaan Pengembangan Tempat-tempat Benda Bersejarah dan Purbakala di Kabupaten Lumajang Provinsi Jawa Timur. Balai Arkeologi Yogyakarta.

Tim Studi. 1995. Laporan Akhir Studi Perencanaan Pengembangan Tempat-tempat Benda Bersejarah dan Purbakala di Kabupaten Tulungagung Provinsi Jawa Timur. Balai Arkeologi Yogyakarta. 